\title{
Sorption of Textile Dyes from Textile Wastewater by Chitosan-based Hydrogel
}

\author{
MARIJA LJ. LUČIĆ ŠKORIĆ, University of Belgrade, \\ Innovation Center of Faculty of Technology \\ and Metallurgy, Belgrade \\ LAZAR S. STANOJKOVIĆ, University of Belgrade, \\ Faculty of Technology and Metallurgy, Belgrade \\ NEDELJKO B. MILOSAVLJEVIĆ, University of Belgrade, \\ Faculty of Technology and Metallurgy, Belgrade \\ MELINA T. KALAGASIDIS KRUŠIĆ, University of Belgrade, \\ Faculty of Technology and Metallurgy, Belgrade
}

Original scientific paper

UDC: 628.3.034.3:677

DOI: 10.5937/tehnika1801009L

With the excessive risks that are present in today's environment, it is of great importance to treat wastewaters before their discharge in water streams. One of the everyday challenges is design of a lowcost and environmentally friendly sorbent such as hydrogel based on chitosan, itaconic and methacrylic acid that can remove wide range of textile dyes. In the present study, this hydrogel has been utilized for investigation of removal of three different azo dyes from simulated textile wastewater: C.I. Basic Blue 9, C.I. Basic Red 1 and C.I. Acid Orange 7. It was found that $p H$ value of the solution had significant effect on dye sorption. Removal of basic dyes was successful at higher $p H$ values, while sorption of acid dye was possible only at low $p H$ value of solution. Simulated textile wastewater is a complex system with various salts, acids and polymers present beside dyes. Regardless of these components, excellent sorption capacity was achieved (more than $80 \%$ of dyes were removed), which makes this hydrogel attractive for use under real conditions.

Key words: hydrogel, sorption, textile dyes, chitosan

\section{INTRODUCTION}

Textile and other dyeing industries are major industrial wastewater sources. The textile industry consumes large quantities of water and produces vast volumes of wastewater from different steps in the dyeing and finishing processes (between 40 and $65 \mathrm{~L} / \mathrm{kg}$ of the product) [1]. Textile wastewater may contain many types of dyes, common inorganic salts, heavy metal ions and solvents. They are among the most aggressive pollutants within the industrial sector and they can cause permanent damage to the aquatic ecosystems if discharged untreated [2].

Also, presence of dyes in textile wastewater is an environmental problem due to their high visibility, resistance and toxic impact. Low concentration of dye

Author's address: Marija Lučić Škorić, University of Belgrade, Innovation Center of Faculty of Technology and Metallurgy, Belgrade, Karnegijeva 4

e-mail: mlucic@tmf.bg.ac.rs

Paper received: 12.01.2018.

Paper accepted: 30.01 .2018 . in water is easily visible and it can reduce photosynthetic activities in aquatic environments by preventing the penetration of light and oxygen [3]. Given their synthetic origin and complex aromatic structures, dyes are non-biodegradable substances and they remain stable under different conditions [4]. In addition, dyes have direct and indirect toxic effects on humans as they are associated with cancer, tumors, skin irritation, allergies, heart defects and mutations $[2,5]$.

Dye-containing wastewaters are generally very difficult to treat [6]. During the past few decades, adsorption methods for dye removal have been proven more advantageous over other various physical, chemical, photochemical, and biological methods [7]. Adsorption is the most commonly used method because it is relatively simple, easy to operate and handle and cost-effective [8]. Many efforts have been made to remove dyes using low-cost adsorbents $[9,10]$.

Recently, naturally occurring materials have become a focus of environmental investigations due to low cost and biodegradability. Chitosan is the second most abundant biopolymer in nature after cellulose 
[11]. It has been widely investigated as an adsorbent to capture dyes from aqueous solutions due to its amine $\left(-\mathrm{NH}_{2}\right)$ groups that can be protonated and thus strongly adsorb dye anions by electrostatic attraction [12]. However, shortcomings of chitosan are unsatisfactory mechanical properties, severe shrinkage and deformation after drying, and solubility under acidic conditions [13].

For that reason, chitosan has to be crosslinked for most applications; however, formed networks have a reduced adsorption capacity in comparison with the linear polymer [14]. To improve the adsorption capacity, chemical modifications of chitosan with acids have been explored [15].

In this study, chitosan, itaconic and methacrylic acid hydrogel was synthetized and used for the removal of textile dyes from simulated textile wastewaters. Removal of three textile dyes from two groups was investigated.

The influence of dye structure, $\mathrm{pH}$ of simulated textile wastewater, presence of each individual component and temperature on the dye removal efficiency was studied as well.

\section{MATERIALS AND METHODS}

\subsection{Materials}

For hydrogel synthesis, chitosan (Ch, Fluka, middle viscous), itaconic acid (IA, Fluka) and methacrylic acid (MA, Sigma A.G.) were used. The crosslinking agent $N, N$ '-methylenebisacrylamide (MBA, Acros), redox pair potassium persulfate (KPS, Merck, p.a.) and potassium pyrosulfate (KPyS, Merck p.a.) were used without further purification. Deionized water was used for all experiments.

Buffer solutions were prepared using disodium hydrogen phosphate $\left(\mathrm{Na}_{2} \mathrm{HPO}_{4}\right.$, Lach-Ner p.a.) and sodium dihydrogen phosphate $\left(\mathrm{NaH}_{2} \mathrm{PO}_{4}\right.$, Lach-Ner p.a.). For the removal, three textile dyes were used (Table 1).

\subsection{Synthesis of hydrogel}

Hydrogel synthesis procedure is described in details elsewhere [16]. In short, $\mathrm{Ch}$ and IA were ionically crosslinked and then MAA and crosslinker MBA were added to obtain Ch/IA/MA hydrogel. Monomers ratio was $\mathrm{Ch} / \mathrm{IA} / \mathrm{MA}=1: 1.56: 10$. Crosslinking agent (MBA) and redox pair (KPS/KPyS) concentration was $0.2 \mathrm{wt} \%$, with respect to the total weight of the reaction mixture. Distilled water was used as a solvent. Nitrogen was bubbled through the mixture for 20 min to remove dissolved oxygen. The reaction mixture was then placed between two glass-plates $(20 \times 5 \times 0.4 \mathrm{~cm})$ sealed with a rubber spacer $(2 \mathrm{~mm}$ thick). Polymerization was carried out at $50^{\circ} \mathrm{C}$ for $3 \mathrm{~h}$ after which hydrogel was cut into discs and left in distilled water that was changed for 7 days to remove all unreacted monomers. The discs were dried at room temperature to obtain xerogels.

\subsection{Removal of azo dyes from solution}

To evaluate sorption behavior of synthetized hydrogels, simulated textile wastewater was used and its composition is given in Table 2 [17].

Initial dye removal tests from simulated textile wastewater by $\mathrm{Ch} / \mathrm{IA} / \mathrm{MA}$ hydrogel was evaluated at $50{ }^{\circ} \mathrm{C}$ in dye solutions prepared in: (a) distilled water at initial $\mathrm{pH},(\mathrm{b})$ distilled water where $\mathrm{pH}$ was in acid and basic region (depending on the structure of dye), (c) tap water at initial $\mathrm{pH}$ and (d) tap water where $\mathrm{pH}$ was in acid and basic region.

Based on the analysis of these results, optimal $\mathrm{pH}$ value for sorption of selected dyes was determined and further experiments were conducted in simulated textile wastewater (Table 2). Effect of each individual components of the simulated textile wastewater on the sorption efficiency of the dye was investigated as well. The effect of temperature on the sorption of dyes has been examined at three different temperatures: 25,35 and $50{ }^{\circ} \mathrm{C}$.

Dye removal experiments were conducted in the following manner: $0.5 \mathrm{~g}$ of hydrogels was immersed in $25 \mathrm{~mL}$ of dye solution or simulated textile wastewater and beakers were places in water bath with mechanical agitation and temperature control (WND14 Memmert, Germany).

During $2 \mathrm{~h}$ of dye removal $(15,30,60,90$ and 120 $\mathrm{min}$ ), $3 \mathrm{~mL}$ of dye solution or simulated textile wastewater were taken to monitor remaining dye concentration by an UV/VIS spectrophotometer Shimatzu 1800, at a maximum absorption wavelength $\left(\lambda_{\max }\right)$ of each dye. The aliquot was then returned to the sample.

Table 1. List of azo dyes used in the study

\begin{tabular}{|l|l|l|l|l|l|}
\hline Anionic dye & Abbreviation & Formula & Supplier & $\lambda_{\max }(\mathrm{nm})$ & M.W. $\left(\mathrm{g} \mathrm{mol}{ }^{-1}\right)$ \\
\hline C.I. Acid Orange 7 & $\mathrm{AO} 7$ & $\mathrm{C}_{16} \mathrm{H}_{11} \mathrm{~N}_{2} \mathrm{NaO}_{4} \mathrm{~S}$ & Cassela & 486 & 350.3 \\
\hline C.I. Basic Red 1 & BR1 & $\mathrm{C}_{28} \mathrm{H}_{31} \mathrm{ClN}_{2} \mathrm{O}_{3}$ & Höchst AG. & 524 & 479.0 \\
\hline C.I. Basic Blue 9 & BB9 & $\mathrm{C}_{16} \mathrm{H}_{18} \mathrm{ClN}_{3} \mathrm{~S}$ & Centrohem & 663 & 319.9 \\
\hline
\end{tabular}


Table 2. Composition of simulated textile wastewater

\begin{tabular}{|c|c|}
\hline Components & $\begin{array}{l}\text { Concentration } \\
\left(\mathrm{mg} \mathrm{L}^{-1}\right)\end{array}$ \\
\hline $\begin{array}{l}\text { Azo dye } \\
\text { - C.I. Acid Orange } 7 \\
\text { - C.I. Basic Red } 1 \\
\text { - C.I. Basic Blue } 9\end{array}$ & 10 \\
\hline Starch & 1500 \\
\hline Sucrose & 2000 \\
\hline Acetic acid & 500 \\
\hline $\mathrm{NaOH}$ & 660 \\
\hline $\mathrm{H}_{2} \mathrm{SO}_{4}$ & 350 \\
\hline $\mathrm{NaCl}$ & 500 \\
\hline
\end{tabular}

The percentage of dye removal from solution due to adsorption was calculated by following equation:

$$
D(\%)=\frac{C_{0}-C_{t}}{C_{0}} \cdot 100
$$

where $C_{0}$ and $C_{\mathrm{t}}\left(\mathrm{mg} \mathrm{L}^{-1}\right)$ are the liquid phase concentrations of dye initially and at time $t$.

\section{RESULTS}

\subsection{Sorption experiments in distilled water}

Preliminary tests were performed in distilled water in order to determine dye sorption ability and capacity of $\mathrm{Ch} / \mathrm{IA} / \mathrm{MA}$ hydrogel, which are $\mathrm{pH}-$ sensitive due to the presence of carboxyl groups ($\mathrm{COOH}$ ) originating from methacrylic and itaconic acid and the amino group $\left(-\mathrm{NH}_{2}\right)$ from the chitosan (data not shown).

Firstly, dyes were removed from aqueous solution prepared in distilled water to determine $\mathrm{pH}$ range suitable for removal of acid dye with anion and basic dyes with cation in its structure. Measured $\mathrm{pH}$ of all three dyes was around 7.0. It was found that sorption of acid dye AO7 was very low and cannot be considered successful. On the other hand, the sorption of the basic dyes was more successful (more than $80 \%$ of the dyes were sorbed).

Main reason for this behavior is the value of the dissociation constant of the functional groups in the hydrogel. Amino groups from chitosan are protonated below its $\mathrm{p} K_{\mathrm{a}}$ value $\left(\mathrm{p} K_{\mathrm{a}}=6.5\right)$, while carboxylic groups in itaconic acid become ionized at $\mathrm{pH}$ above 3.85 and 5.44 (p $K_{\mathrm{a} 1}$ and $\mathrm{p} K_{\mathrm{a} 2}$, respectively) as well as in methacrylic acid $\left(\mathrm{p} K_{\mathrm{a}}=4.66\right)$ [18]. Hence, it is necessary to set optimal $\mathrm{pH}$ value to enable formation of interaction between groups from hydrogel and dyes.

For that reason, $\mathrm{pH}$ was adjusted in the following experiment to allow protonation of amino groups in the solution with an dye $\mathrm{AO} 7(\mathrm{pH}=3.0)$ and the dissociation of the carboxyl groups in dye solutions of the dyes BB9 and BR1 (pH =9.0).
It was found that with adjustment of $\mathrm{pH}$ significant increase in sorption was achieved and $84 \%$ of $\mathrm{AO} 7$ was removed from the solution after $2 \mathrm{~h}$ due to electrostatic interactions between $-\mathrm{NH}_{3}{ }^{+}$from chitosan and anion from dye. The removal of basic dyes was not changed substantialy with further increase of solution $\mathrm{pH}$, but the removal degree was at the satisfactory level (more than $80 \%$ was removed during $2 \mathrm{~h}$ ).

\subsection{Sorption experiments in tap water}

Since textile industry rarely uses distilled water in real-life conditions, further experiments were performed with dye solution prepared in tap water. Also, influence of each individual component found in the simulated textile wastewater on the removal degree is investigated and given in Table

3. Unlike distilled water, in tap water different ions $\left(\mathrm{Ca}^{2+}, \mathrm{HCO}_{3}^{-}, \mathrm{Mg}^{2+}, \mathrm{SO}_{4}{ }^{2-}\right.$, etc. $)$ are present, which influence directly removal of dyes. They form interactions with groups in hydrogel and thus leave less active sites for hydrogel to interact with dyes.

As in previous experiment, the temperature was maintained at $50{ }^{\circ} \mathrm{C}$ and the $\mathrm{pH}$ value was adjusted to $\mathrm{pH}=3$ in the acid dye solution and $\mathrm{pH}=9$ in basic dyes solution. The results are given in Table 3.

Table 3. Effect of each individual components of the simulated textile wastewater to the sorption efficiency of the dye at $50^{\circ} \mathrm{C}$

\begin{tabular}{|l|l|l|l|}
\hline \multirow{2}{*}{ Component } & \multicolumn{3}{|l|}{ Dye removal $(D)$ after 120 min, \% } \\
\cline { 2 - 4 } & $\begin{array}{l}\text { BB9 } \\
(\mathrm{pH} 9)\end{array}$ & $\begin{array}{l}\text { BR1 } \\
(\mathrm{pH} 9)\end{array}$ & $\begin{array}{l}A O 7 \\
(\mathrm{pH} 3)\end{array}$ \\
\hline Tap water & 82 & 85 & 89 \\
\hline Starch & 76 & 78 & 84 \\
\hline Acetic acid & 73 & 74 & 84 \\
\hline $\mathrm{NaOH}$ & 75 & 75 & 87 \\
\hline $\mathrm{NaCl}^{\mathrm{H}}$ & 73 & 78 & 86 \\
\hline $\mathrm{H}_{2} \mathrm{SO}_{4}$ & 75 & 77 & 87 \\
\hline
\end{tabular}

It can be observed that high degree of dye sorption from tap water for all three dyes have been achieved $(>80 \%)$. Although different ions are present in the tap water, they do not interfere with the dye sorption process from the solution. The influence of each individual component from simulated textile wastewater (Table 3) on the efficiency of dye sorption was also examined. Each component was added to the dye solution in tap water at the concentration usually found in textile wastewater (Table 2).

Main reason for this experiment was to determine whether some of the components that are, according to the literature, most often found in the textile wastewater have a significant effect on the sorption of 
the selected dyes by $\mathrm{Ch} / \mathrm{IA} / \mathrm{MA}$ hydrogel (Table 3). After detailed analysis of the results, it was found that none of the wastewater components significantly change the final degree of removed dyes when compared to the results obtained in tap water (Table 3).

\subsection{Sorption of dye from simulated textile wastewater}

During the dying process, except for dyes, other materials are used and each component has a specific function. Usually these materials are salts, acids or polymers that are used to improve dying efficiency, but they end up in wastewater as well, which makes wastewater treatment more complicated [16]. Measured $\mathrm{pH}$ value of simulated textile wastewater is in the range from 1.9 to 2.6 for all three dye solutions. Since it is shown that $\mathrm{pH}$ of solution plays an important role at the removal efficiency, the sorption of dyes from simulated textile wastewater was performed at three different $\mathrm{pH}(\mathrm{pH}=3.0,6.0$ and 9.0).

Removal of dye BB9 at $\mathrm{pH}=9$ and $50^{\circ} \mathrm{C}$ from simulated textile wastewater is given in Fig. 1. During two hours of dye sorption, it was observed that the peak denoting the maximum wavelength of dye in the UV/VIS spectrum alternately disappears and recurs. This behavior was unexpected (Fig. 1).

In concentrated aqueous $\mathrm{NaOH}$ solutions containing BB9 and glucose stirring process leads to the formation of glucose enolate, which participates in the oxidation-reduction reaction with BB9. Glucose is oxidized to gluconic acid, which in the alkaline solution has the form of sodium gluconate, while BB9 reduces to a colorless leukomethylene blue. In the UV/VIS spectrum, leukomethylene blue does not show the absorption peak and indicating that all dye is removed from the solution. This phenomenon is called the effect of "blue bottle". If there is sufficient oxygen and stirring, leuko-methylene blue is oxidized to BB9 and dye solution is again blue. With continuous stirring, the entire process is repeated and color of the solution can be changed several times (the number of cycles depends on the available oxygen) [19].

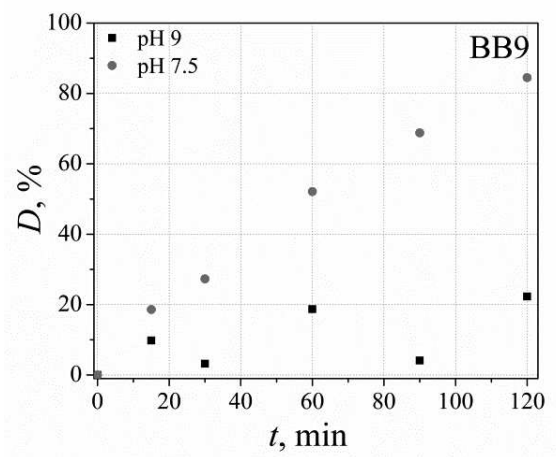

Figure 1 - Sorption of BB9 dye from simulated textile wastewater at $50^{\circ} \mathrm{C}$ with sucrose
In order to avoid the effect of "blue bottle" and to evaluate BB9 dye removal from the aqueous solution, $\mathrm{pH}$ of wastewater was adjusted and maintained in alkaline environment with $\mathrm{pH}$ just slightly above 7.0. Fig. 1 shows that at $\mathrm{pH} 7.5$, "blue bottle" effect was avoided and the dye was successfully removed ( $>$ $80 \%)$.

To avoid "blue bottle" effect, further experiments were performed in simulated waste-water free of sucrose. Sorption of BB9 was first monitored at a low $\mathrm{pH}(\mathrm{pH}=3.0)$ for 50 minutes, then the $\mathrm{pH}$ was increased to 9.0 (Figure 2). During the first $50 \mathrm{~min}$ dye removal degree was very low (Figure 2a). However, only $10 \mathrm{~min}$ after the $\mathrm{pH}$ value was increased to 9.0 the color of the dye solution changed significantly. Final dye removal degree of BB9 dye was $72 \%$, which confirmed once more necessity of alkaline environment for the effective removal of basic dye when $\mathrm{Ch} / \mathrm{IA} / \mathrm{MA}$ hydrogel is used as sorbent. Also, a complex composition of simulated textile wastewater did not affect the efficiency of dye sorption on the hydrogel. Hydrogel discs were intensively colored after sorption was completed, confirming that these hydrogels can be used for the removal of BB9 (Fig. 2c).
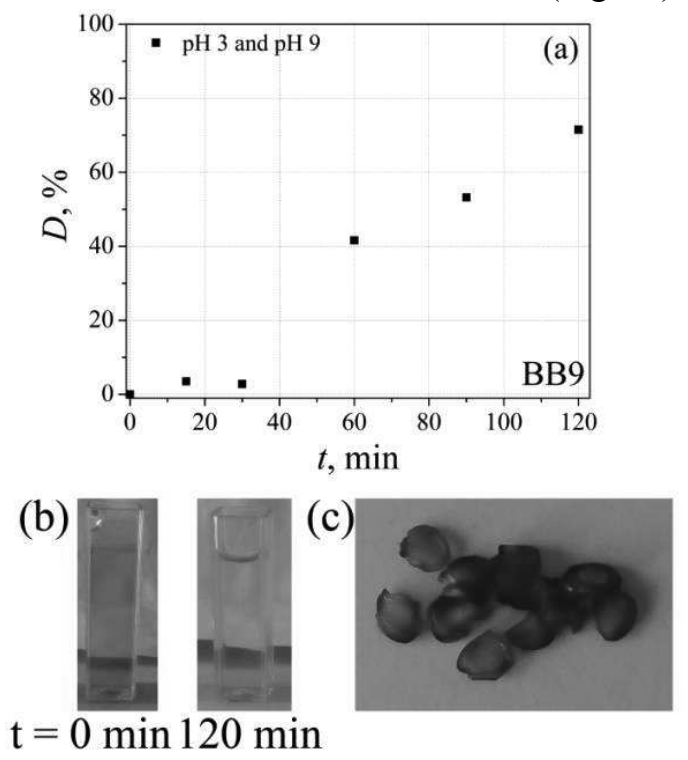

Figure 2 - (a) Sorption of BB9 dye from simulated textile wastewater at $50{ }^{\circ} \mathrm{C}$ without sucrose at $p H=3(50 \mathrm{~min})$ and $\mathrm{pH}=9(50-120 \mathrm{~min}) ;(b)$ Photographs of cuvette with BB9 dye solution at different time intervals; (c) Photograph of Ch/IA/MA hydrogels after removal of $B B 9$

Afterwards, sorption of the dye BR1 was investigated (Figure 3). First, sorption was monitored at low $\mathrm{pH}(\mathrm{pH}=3.0)$ and, as expected, the concentration of dye remained almost constant during $2 \mathrm{~h}$ due to inability to form interactions with carboxylic groups from hydrogel (Figure 3a). Afterwards, the $\mathrm{pH}$ was adjusted to 6.0 (Figure 3a) and photographs of 
cuvettes with solution are presented in Fig. 3b. At the beginning of measurement, an intensive orange color of dye solution is present, but after $60 \mathrm{~min} 66 \%$ of the dye was sorbed from the solution and intensity of color in the cuvette decreased (Figure 3b). Finally, after 120 minutes $87 \%$ of the dye was removed. The simulated wastewater remained slightly colored (Figure 3b), whereas the hydrogel discs were intensively orange (Figure $3 b$ ). Sorption of the dye from the solution at $\mathrm{pH} 9.0$ was also successful since $80 \%$ of dye was removed after $2 \mathrm{~h}$. Similar dye removal results were obtained in distilled water confirming that $\mathrm{pH}$ value of the solution is one of the most important effects on the removal efficiency of dye BR1.

The influence of sucrose on sorption of BR 1 dye is shown as insert in Figure 3a. When the dye removal results from simulated wastewater with and without sucrose are compared, under the same experimental conditions $(\mathrm{pH}=6.0)$ it can be seen that sucrose does not affect the sorption efficiency of the dye from the solution and same removal degree was achieved in both cases after $2 \mathrm{~h}$.
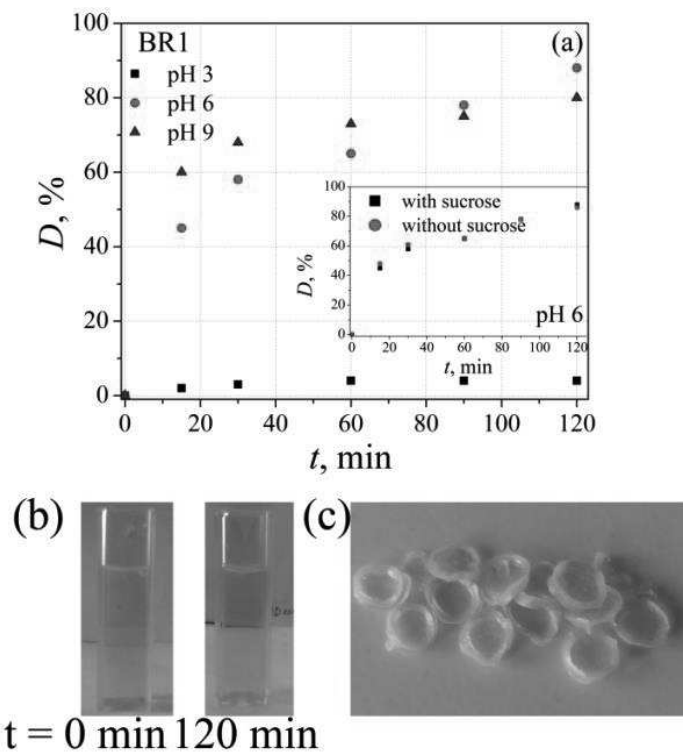

Figure 3-(a) The effect of pH on sorption of BR1 dye from simulated textile wastewater without sucrose at $50{ }^{\circ} \mathrm{C}$ and the effect of sucrose on BR1 sorption at pH 6 (insert); (b) Photographs of cuvette with BR1 dye solution at different time intervals ( $\mathrm{pH}$ 6); (c) Photograph of Ch/IA/MA hydrogels after removal of BRI

Several types of dyes are used for dyeing of different materials in textile industry, but one of the most common are acid dyes. Typical representative from this group is AO7, which removal was also investigated at $\mathrm{pH}$ 3.0, 6.0 and 9.0 (Fig. 4). Unlike removal of basic dyes, negligible removal degree of acid dye $\mathrm{AO} 7$ was obtained at higher $\mathrm{pH}$ values $(\mathrm{pH}$ 6.0 and 9.0). On the other hand, when $\mathrm{pH}$ was 3.0 significant sorption is achieved (83\%). As in previous case, presence of sucrose in the simulated textile wastewater did not significantly affect sorption process of AO7 dye (Figure 4a, insert).

At the beginning of the measurement, dye solution is the intensively colored, but as the sorption process progresses the color intensity of the solution decreases. Dye solution is only slightly colored after $2 \mathrm{~h}$ (Figure $4 \mathrm{~b}$ ). It is expected that complete dye removal could be achieved if sorption time is longer. Hydrogel discs, dried after the experiment, are shown in Figure $4 \mathrm{c}$. The intensive red-orange color of the discs originates from the bound dye in the hydrogel.
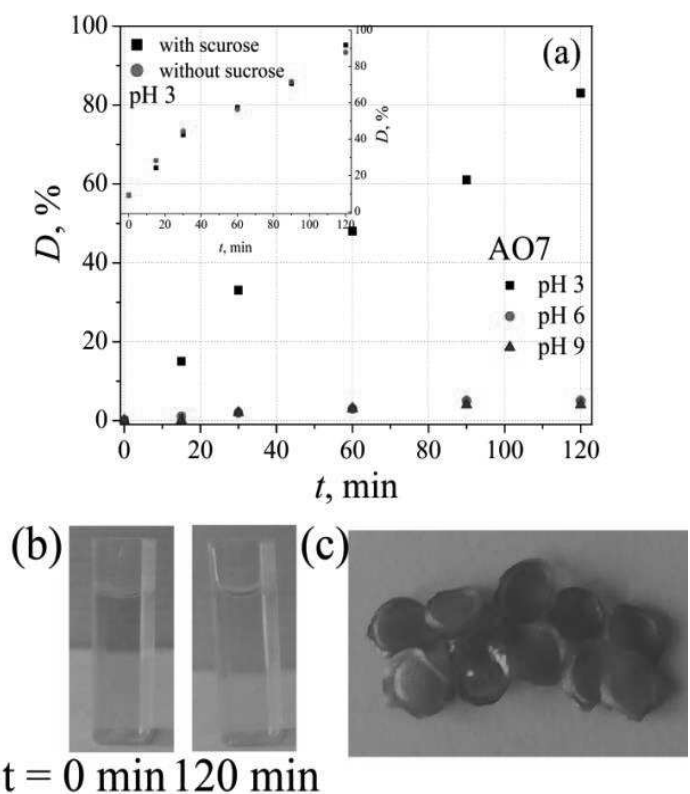

Figure 4 - (a) The effect of $\mathrm{pH}$ on sorption of AO7 from simulated textile wastewater without sucrose at $50{ }^{\circ} \mathrm{C}$ and the effect of sucrose on $\mathrm{AO} 7$ sorption at pH 3 ("insert"); (b) Photographs of cuvette with AO7 dye solution at different time intervals; (c) Photograph of Ch/IA/MA hydrogels after removal of $A O 7$

\subsection{Influence of temperature}

According to the literature, during the release the temperature of textile industry wastewater is in the range of from $25^{\circ} \mathrm{C}$ to $65^{\circ} \mathrm{C}$ [20]. In previous experiments, optimal $\mathrm{pH}$ value for sorption of investigated dyes from simulated textile wastewater was determined after which influence of temperature was evaluated. Sorption of dyes was monitored at three different temperatures: $25^{\circ} \mathrm{C}, 35^{\circ} \mathrm{C}$ and $50^{\circ} \mathrm{C}$, while the $\mathrm{pH}$ of the solution for each dye is set to the optimal value.

When the temperature increases from $5{ }^{\circ} \mathrm{C}$ to $55 \mathrm{C}$, the degree of swelling slightly increases as a result of association/dissociation of inter- and intramolecular hydrogen bonds within the hydrogel [16]. Therefore, it is of great importance to examine these 
two parameters when $\mathrm{Ch} / \mathrm{IA} / \mathrm{MA}$ hydrogel are used for removal of dyes, since they can vary greatly when wastewater is released from textile factories.
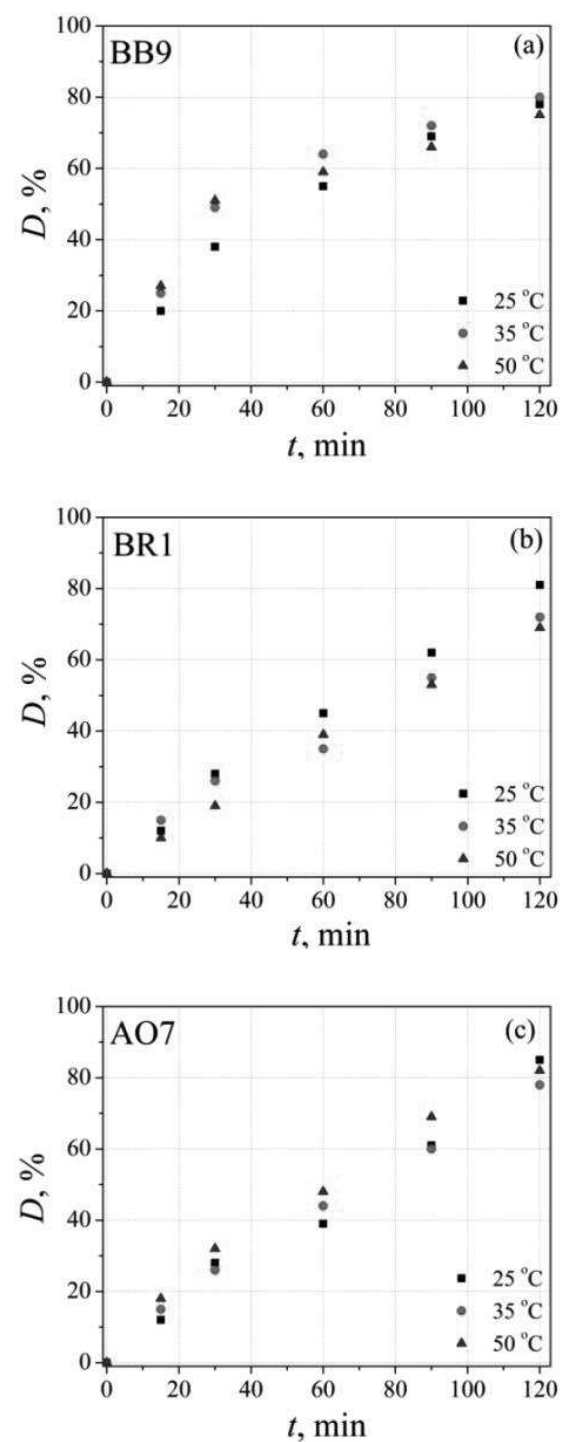

Figure 5 - The effect of temperature on dye sorption from simulated textile wastewater without sucrose: (a) C.I. Basic Blue 9 (pH 9), (b) C.I. Basic Red 1 ( $p H$ 9), (c) C.I. Acid Orange 7 (pH 3)

Figure 5 shows the effect of temperature on the sorption of dyes from simulated textile wastewater. With increase of temperature from $25{ }^{\circ} \mathrm{C}$ to $50{ }^{\circ} \mathrm{C}$ there is no noteworthy difference in dye removal. The temperature in the investigated range does not influence sorption of acid and basic dyes at optimal $\mathrm{pH}$ conditions. It was shown in previous research that $\mathrm{Ch} / \mathrm{IA} / \mathrm{MA}$ hydrogels do not show substantial temperature sensitivity in range from $5{ }^{\circ} \mathrm{C}$ to $50^{\circ} \mathrm{C}$ [17]; hence, it was expected that efficiency of dye sorption by this hydrogel does not change significantly when the temperature changes.

\section{CONCLUSION}

$\mathrm{pH}$-sensitive $\mathrm{Ch} / \mathrm{IA} / \mathrm{MA}$ hydrogel successfully removed three azo dyes (C.I. Basic Blue 9, C.I. Basic Red 1 and C.I. Acid Orange 7) and decolorized dye solutions prepared in simulated textile wastewater. In such systems azo dyes are removed via electrostatic interaction between cation or anion in dye molecule and carboxyl $(-\mathrm{COOH})$ or amino group $\left(-\mathrm{NH}_{2}\right)$ in hydrogel.

Preliminary tests were performed in distilled or tap water with different components present in simulated textile wastewater; it was found that these dyes could be removed from solution and hydrogel was successful in dye removal. Further examinations were performed in simulated textile wastewater due to its complexity.

It was observed that $\mathrm{pH}$ value of dye solution has substantial effect on the efficiency of sorption of the tested dyes. Negatively charged carboxylic groups at higher $\mathrm{pH}$ values attract and bind cations from basic dyes, while the positively charged amino group at the low $\mathrm{pH}$ attract and bind anions of acid dyes. $\mathrm{Ch} / \mathrm{IA} / \mathrm{MA}$ hydrogel sorbed all three tested dyes with high efficiency $(>75 \%)$ from simulated wastewater at the appropriate $\mathrm{pH}$ value. Further, temperature does not affect the sorption process of the dyes in the range from $25^{\circ} \mathrm{C}$ to $50{ }^{\circ} \mathrm{C}$ and overall good removal efficiency was achieved. Obtained results indicate that synthetized hydrogel can be used for the removal of different types of textile dyes, regardless of their structure and temperature at which sorption is performed.

\section{ACKNOWLEDGMENT}

The authors would like to acknowledge funding from the Ministry of Education, Science and Technological Development of the Republic of Serbia, through Project No. 172062.

\section{REMARK}

The paper was presented at the 16th Young researchers' conference, Materials science and engineering, Belgrade, December 6-8, 2017.

\section{REFERENCES}

[1] Mezohegyi G, van der Zee FP, Font J, Fortuny A, Fabregat A, Towards advanced aqueous dye removal processes: A short review on the versatile role of activated carbon, Journal of Environmental Management, Vol. 102, pp. 148-164, 2012.

[2] Xu Y. C, Wang Z. X, Cheng XQ, Xiao YC, Shao L, Positively charged nanofiltration membranes via economically mussel-substance-simulated co-deposition for textile wastewater treatment, Chemical Engineering Journal, vol. 303, pp. 555-564, 2016. 
[3] Khataee A. R, Kasiri MB. Photocatalytic degradation of organic dyes in the presence of nanostructured titanium dioxide: Influence of the chemical structure of dyes, Journal of Molecular Catalysis. A: Chemical, vol. 328, pp. 8-26, 2010.

[4] Harikumar P. S, Joseph L, Dhanya A, Photo-catalytic degradation of textile dyes by hydrogel supported titanium dioxide nanoparticles, Journal of Environmental Engineering and Ecological Science, vol. 2, 2013.

[5] Khosravi M, Azizian S, Adsorption of anionic dyes from aqueous solution by iron oxide nanospheres, Journal of Industrial and Engineering Chemistry, vol. 20, pp. 2561-2567, 2014.

[6] Zhu H. Y, Jiang R, Fu Y. Q, Jiang JH, Xiao L, Zeng GM. Preparation, characterization and dye adsorption properties of $\gamma-\mathrm{Fe}_{2} \mathrm{O}_{3} / \mathrm{SiO}_{2} /$ chitosan composite, Applied Surface Science, vol. 258, pp. 1337-1344, 2011.

[7] Zhang R, Su Y, Zhao X, Li Y, Zhao J, Jiang Z. A, novel positively charged composite nanofiltration membrane prepared by bio-inspired adhesion of polydopamine and surface grafting of poly(ethylene imine), Journal of Membrane Science, vol. 470, pp. 9-17, 2014.

[8] Goswami M, Phukan P. Enhanced adsorption of cationic dyes using sulfonic acid modified activated carbon, Journal of Environmental Chemical Engineering, vol. 5, pp. 3508-3517, 2017.

[9] Mittal A, Malviya A, Kaur D, Mittal J, Kurup L. Studies on the adsorption kinetics and isotherms for the removal and recovery of Methyl Orange from wastewaters using waste materials, Journal of Hazardous Materials, vol. 148, pp. 229-240, 2007.

[10]Nandi B. K, Goswami A, Purkait M. K, Removal of cationic dyes from aqueous solutions by kaolin: Kinetic and equilibrium studies, Applied Clay Science, vol. 42, pp. 583-590, 2009.

[11]Cui L, Xiong Z, Guo Y, Liu Y, Zhao J, Zhang C, Zhu $\mathrm{P}$, Fabrication of interpenetrating polymer network chitosan/gelatin porous materials and study on dye adsorption properties, Carbohydrate Polymers, vol. 132, pp. 330-337, 2015.

[12]Shajahan A, Shankar S, Sathiyaseelan A, Narayan K. S, Narayanan V, Kaviyarasan V, Ignacimuthu S, Comparative studies of chitosan and its nanoparticles for the adsorption efficiency of various dyes, International Journal of Biological Macromolecules, vol. 104, pp. 1449-1458, 2017.

[13]He J, Wang F, Wu Y, Huang Y, Zhang H, Preparation of the water-soluble chitosan-coated oxidized regenerated cellulose gauze, Cellulose, vol. 18, pp. 1651-1659, 2011.

[14]Kayaman N, Hamurcu E. G, Uyanik N, Baysal B. M, Interpenetrating hydrogel networks based on polyacrylamide and poly(itaconic acid): synthesis and characterization, Macromolecular Chemistry and Physics, vol. 200, pp. 231-238, 1999.

[15]Pulat M, Asıl D, Fluconazole release through semiinterpenetrating polymer network hydrogels based on chitosan, acrylic acid, and citraconic acid, Journal of Applied Polymer Science, vol. 113, pp. 2613-2619, 2009.

[16]Milosavljevic N, Ristic M, Peric-Grujic A, Filipovic J, Strbac S, Rakocevic Z, Kalagasidis Krusic M, Sorption of zinc by novel $\mathrm{pH}$-sensitive hydrogels based on chitosan, itaconic acid and methacrylic acid, Journal of Hazardous Materials, vol. 192, pp. 846854, 2011.

[17]Işık M, Sponza D. T. Anaerobic/aerobic treatment of a simulated textile wastewater, Separation and Purification Technology, vol. 60, pp. 64-72, 2008.

[18]Weast R. C. Handbook of Chemistry and Physics 55th Edition, CRC Press, Cleveland OH, 1974.

[19]Buchoff L. S, Ingberz N. M, Bradyi J. H, Colorimetric Determination of low Concentrations of Dissolved Oxygen in Water, Analitycal Chemistry, vol. 27, pp. 1401-1404, 1955.

[20]Dey S. Islam A, A Review on Textile Wastewater Characterization in Bangladesh, Resources and Environment, vol. 5, pp. 15-44, 2015. 


\section{REZIME}

\section{SORPCIJA BOJA ZA TEKSTIL IZ TEKSTILNIH OTPADNIH VODA POMOĆU HIDROGELA NA BAZI HITOZANA}

Zbog sve više rizika koji se javljaju po životnu sredinu, veoma je važno prečistiti otpadne vode pre njihovog ispuštanja u vodotokove. Zato je jedan od izazova današnjih istraživanja dizajn jeftinog $i$ ekološki prihvatljivog sorbenta, kao što je hidrogel na bazi hitozana, itakonske i metakrilne kiseline, koji može da ukloni širok spektar tekstilnih boja. U ovom radu je korišćen hidrogel za ispitivanje uklanjanja tri različite azo boje iz simulirane otpadne vode iz tekstilne industrije: C.I. Basic Blue 9, C.I. Basic Red 1 i C.I. Acid Orange 7. Utvrđeno je da pH vrednost rastvora značajno utiče na sorpciju boja. Uklanjanje baznih boja je uspešno pri višim pH vrednostima, dok je sorpcija kisele boje moguća samo pri niskoj pH vrednosti rastvora. Simulirana otpadna voda iz tekstilne industrije je složen sistem sačinjen od različith soli, kiselina i polimera koji su prisutni pored boja za tekstil. Bez obzira na ove komponente, ostvaren je odličan kapacitet sorpcije (uklonjeno je više od $80 \%$ boje iz rastvora), što ovaj hidrogel čini atraktivnim za upotrebu u realnim sistemima.

Ključne reči: hidrogel, sorpcija, boje za tekstil, hitozan 